\title{
Study of the Influence of Microwave and Conventional Heating on the Lipase-Catalyzed Esterification of Lauric Acid with Different Alcohols
}

\author{
Velia Osuna ${ }^{1}$ and Ignacio A. Rivero ${ }^{1,2 *}$ \\ ${ }^{1}$ Centro de Graduados e Investigación del Instituto Tecnológico de Tijuana. Apartado Postal 1166, Tijuana, B.C. 22000 \\ México.irivero@tectijuana.mx. \\ ${ }^{2}$ Instituto Nacional de Investigaciones Nucleares, Departamento de Química. Carretera México Toluca S/N, La Marquesa, \\ Ocoyoacac, México, D.F. C.P. 52750
}

Received January 5, 2012; accepted April 2, 2012

\begin{abstract}
In a systematic study, three commercial lipases were used for the esterification of lauric acid with six different alcohols: methanol, ethanol, propanol, butanol, pentanol, and allyl alcohol, under conventional heating and microwave irradiation. Optimization of reaction conditions included reaction time and effect of temperature under microwave irradiation and conventional heating. The optimum reaction temperature was previously established in enzymatic esterification by conventional heating. Novozyme 435, lipase (Pseudomonas cepacia) immobilized in diatomite (PS-DI) and lipase ( . cepacia) immobilized in ceramic (PS-CI) were used in this study. The latter showed the highest activity, therefore, this enzyme was used to investigate the variation of reaction time under microwave heating. The stability of immobilized lipases under classical heating and under the microwave irradiation was studied by visual analysis of the immobilized matrix by scanning electron microscopy (SEM).
\end{abstract}

Keywords: Lipases, alcohols, esterification, microwave irradiation, lauric acid.

\section{Introduction}

Preparation of organic esters plays a major role in the production of flavors, fragrances, solvents, plasticizers, pesticides herbicides, medicinal and surface-active agents [1]. The intermediate products are obtained as extracts from naturally occurring materials, but they are not sufficient to fulfill the growing demands [2]. The use of enzymes in organic synthesis has been recognized as a very powerful tool [3], particularly after the discovery of the stability and activity of enzymes in organic solvents [4]. The role of biocatalysis is expected to increase in the near future [5], with the easy and low cost production of enzymes from recombinant organisms, and the expansion of the substrate scope of enzymes, relying on a high throughput selection and direct evolution [6].

Lipases are one of the important enzymes and are well known as biocatalysts. They are very useful in organic synthesis, mainly for hydrolysis, esterification, transesterification, etc [7a-c]. Lipase-catalyzed reactions have recently received greater consideration in the traditional chemical synthetic methods, particularly in the production of fragrances and natural flavors [8]. This is due to the substrate specificity and regiospecificity, expressed by most lipases, the mild reaction conditions, the degree of purity of the products, and they do not require labile
Resumen. En este estudio sistemático, tres lipasas comerciales se utilizaron para la esterificación del ácido láurico con seis diferentes alcoholes: metanol, etanol, propanol, butanol, pentanol, y alcohol alílico, utilizando calentamiento convencional y la radiación por microondas. Se optimizaron las condiciones de reacción; tiempo de reacción y la temperatura por calentamiento convencional y por radiación de microondas. Se estableció previamente la temperatura óptima de reacción en la esterificación enzimática por calentamiento convencional. Las lipasas Novozyme 435, aislada de la Pseudomonas cepacia e inmovilizada en tierra de diatomeas (PS-DI) y la aislada de la $P$. cepacia inmovilizada en cerámica (PS-CI), fueron utilizadas en este estudio. La última presentó la mayor actividad, por lo tanto se utilizó para investigar el efecto del tiempo de reacción con calentamiento por microondas. La estabilidad de las lipasas inmovilizadas tanto por calentamiento convencional como con radiación por microondas fue monitoreada al estudiar la morfología de la matriz por microscopia electrónica de barrido (SEM).

Palabras clave: Lipasas, alcoholes, esterificación, irradiación pro microondas acido láurico.

cofactors $[9,10]$. Lipases have been immobilized on different solid supports and their stability has been proven [11a-c]. Enzyme reactions have been activated by microwave and good yields were obtained [12a-d].

One of the new approaches towards clean and green chemistry is the application of microwaves, which is an alternative to conventional heating technique, because it provides an effective activation method, which reduce the potential barrier and produce the thermodynamic product in an easy way; this effect occurs through the interaction between the microwave energy and dipole moments of the starting materials [13].

Since lipase-catalyzed reactions are rather sluggish in nature, the synergism with microwave can be expected to enhance the reaction rates. Such an exploration has been tried out earlier to witness rate enhancement in microwave irradiated lipasecatalyzed reactions [14].

In the present work three different lipases, which were used in the catalyzed esterification of lauric acid with several n-alcohols in the presence of three commercial lipases were investigated. The reactions were performed under conventional heating and under the microwave irradiation; the stability of immobilized lipases matrix were studied under both irradiation methods by scanning electron microscopy (SEM). 


\section{Experimental}

\section{General procedures}

Thin-layer chromatography (TLC) was performed on silica gel $\mathrm{F}_{254}$ plates (Merck). All compounds were detected using UV light. ${ }^{1} \mathrm{H}$ and ${ }^{13} \mathrm{C}$ nuclear magnetic resonance spectra at $200 \mathrm{~Hz}$ and $50.289 \mathrm{~Hz}$, respectively, were recorded on a Varian Mercury $200 \mathrm{MHz}$ Spectrometer in $\mathrm{CDCl}_{3}$ with TMS as internal standard. Mass spectra were obtained on a Hewlett- Packard 5989 by EI at $70 \mathrm{eV}$. Microwave equipment was a selftuning single mode CEM Discover ${ }^{\mathrm{TM}}$ Focused synthesizer.

\section{Enzyme and chemicals}

Immobilized lipase; Novozym 435 (triacylglycerol hydrolase, EC 3.1.1.3, from Candida antarctica supported on acrylic resin beads) was obtained from Novozymes México. Lipase (Pseudomonas cepacia) (PS-CI) (immobilized on ceramic) and lipase (Pseudomonas cepacia) (PS-DI) (immobilized on diatomite), were purchased from Amano Pharmaceutical Co. All enzymes were used without previous treatment.

All chemicals were obtained from Sigma-Aldrich and used without further purification: lauric acid, methanol, ethanol, $n$ propanol, $n$-butanol, $n$-pentanol, $n$-allyl alcohol.

\section{Lipase-Catalyzed esterification}

\section{Conventional heating}

The lipase-catalyzed reaction was initiated by mixing lauric acid (250 mg, $0.01 \mathrm{~mol}$ ), $0.01 \mathrm{~mol}$ of $n$-alcohol (the molar ratio alcohol /lauric acid was $1: 1)$, and $15 \mathrm{mg}$ of lipase $(6 \% \mathrm{w} / \mathrm{w})$ in $10 \mathrm{~mL}$ of hexane in a $50-\mathrm{mL}$ screw-capped bottle. The reaction was carried out on a water bath at controlled temperature $\left(35,45\right.$, and $\left.55^{\circ} \mathrm{C}\right)$ with magnetic stirring at $250 \mathrm{rpm}$ for $24 \mathrm{~h}$. Progress of the reaction was monitored by withdrawing aliquots taken at intervals and centrifuged at 10,000 rpm. The supernatant was analyzed by Gas Chromatography (GC). The reaction is shown in scheme 1 .

\section{Microwave assisted synthesis}

The esterification catalyzed by lipase under microwave irradiation was carried out by adding lauric acid $(250 \mathrm{mg}, 0.01$ mol), $0.01 \mathrm{~mol}$ of $n$-alcohol (the molar ratio alcohol /lauric acid was $1: 1)$, and $15 \mathrm{mg}$ of lipase $(6 \% \mathrm{w} / \mathrm{w})$ and hexane (10 $\mathrm{mL}$ ) in Pyrex microwave process vials. The microwave irradiation was performed in a monomode microwave reactor (CEM Discovery ${ }^{\mathrm{TM}}$ ) fitted with a stirring system under controlled temperature mode. All reactions were performed in closed ves-

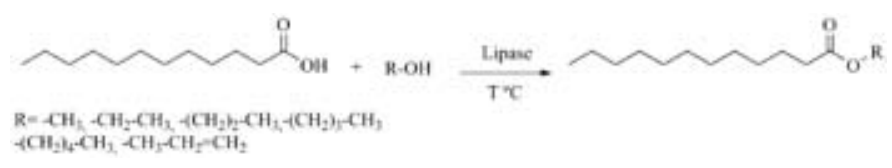

Scheme 1. Enzymatic esterification reaction. sels and the pressure monitored by the microwave equipment with the maximum stirring speed available in the reactor. The reactions assisted by microwave were monitored by GC-MS. The temperature effect on esterification was evaluated at different temperatures $\left(40-90^{\circ} \mathrm{C}\right)$. The reactions were heated under microwave irradiation at $40 \mathrm{~W}$ for 5 min (Optimum reaction time was previously calculated).

\section{Product identification}

The products were analyzed by Nuclear Magnetic Resonance ${ }^{1} \mathrm{H}(200 \mathrm{MHz})$ and ${ }^{13} \mathrm{C}$ spectra $(50 \mathrm{MHz})$ recorded on a Varian Mercury $200 \mathrm{MHz}$ Spectrometer with $\mathrm{CDCl}_{3}$ and TMS as internal standard. Mass spectra were obtained on a Hewlett- Packard 5989 by EI at $70 \mathrm{eV}$.

Methyl dodecanoate: ${ }^{1} \mathrm{H}$ NMR: $\delta 3.66\left(\mathrm{~s}, 3 \mathrm{H}, \mathrm{CH}_{3}-\mathrm{O}\right)$, $2.30\left(\mathrm{t}, 2 \mathrm{H}, J=7.5 \mathrm{~Hz},-\mathrm{CH}_{2} \mathrm{COO}\right), 1.60\left(\mathrm{dd}, 2 \mathrm{H}, J_{1}=7.5, J_{2}\right.$ $\left.=14.5 \mathrm{~Hz},-\mathrm{CH}_{2}-\mathrm{C}-\mathrm{COO}\right), 1.26\left(\mathrm{~s}, 16 \mathrm{H},-\left(\mathrm{CH}_{2}\right)_{8^{-}}\right), 0.88(\mathrm{t}, 3 \mathrm{H}$, $\left.\mathrm{CH}_{3}-\mathrm{C}\right) .{ }^{13} \mathrm{C}$ NMR: $\delta$ 174.3, 51.4, 34.1, 31.9, 29.6, 29.5, 29.3, 29.2, 25.0, 22.7, 14.1. MS (m/z): 214(5\%).

Ethyl dodecanoate: ${ }^{1} \mathrm{H}$ NMR: $\delta 4.12(\mathrm{q}, 2 \mathrm{H}, J=7.1 \mathrm{~Hz}$, $\left.-\mathrm{CH}_{2}-\mathrm{O}\right), 2.30\left(\mathrm{dd}, 2 \mathrm{H}, J_{1}=5.3, J_{2}=12.7 \mathrm{~Hz},-\mathrm{CH}_{2} \mathrm{COO}\right)$, $1.60\left(\mathrm{~m}, 2 \mathrm{H},-\mathrm{CH}_{2}-\mathrm{C}-\mathrm{COO}\right) 1.26\left(\mathrm{t}, 19 \mathrm{H}, J=7.1 \mathrm{~Hz},-\left(\mathrm{CH}_{2}\right)_{8}{ }^{-}\right.$, $\left.\mathrm{CH}_{3}-\mathrm{C}-\mathrm{O}\right), 0.88$ (t, $\left.3 \mathrm{H}, J=6.4, \mathrm{CH}_{3}-\mathrm{C}\right) .{ }^{13} \mathrm{C}$ NMR: $\delta 173.9$, 60.1, 34.4, 31.9, 29.6, 29.5, 29.3, 29.1, 29.1, 25.0, 22.7, 14.2, 14.1. MS (m/z): 228(4\%).

Propyl dodecanoate: ${ }^{1} \mathrm{H}$ NMR: $\delta 4.03(\mathrm{t}, 2 \mathrm{H}, J=6.7 \mathrm{~Hz}$, $\left.-\mathrm{CH}_{2}-\mathrm{O}\right), 2.30\left(\mathrm{t}, 2 \mathrm{H}, J=7.5 \mathrm{~Hz},-\mathrm{CH}_{2} \mathrm{COO}\right), 1.63\left(\mathrm{td}, 4 \mathrm{H}, J_{1}\right.$ $\left.=6.9, J_{2}=13.9 \mathrm{~Hz},-\mathrm{CH}_{2}-\mathrm{C}-\mathrm{COO},-\mathrm{CH}_{2}-\mathrm{C}-\mathrm{O}\right), 1.30(\mathrm{~S}, 16 \mathrm{H}$, $\left.-\left(\mathrm{CH}_{2}\right)_{8^{-}}\right), 0.90\left(\mathrm{td}, 6 \mathrm{H}, J_{1}=3.8, J_{2}=7.1 \mathrm{~Hz}, \mathrm{CH}_{3}-\mathrm{C}-\mathrm{C}-\mathrm{O}, \mathrm{CH}_{3^{-}}\right.$ C). ${ }^{13} \mathrm{C}$ NMR: $\delta$ 174.1, 65.9, 34.4, 31.9, 29.6, 29.5, 29.3, 29.3, 29.2, 25.0, 22.7, 22.0, 14.1, 10.4. MS (m/z): 242(7\%).

Allyl dodecanoate: ${ }^{1} \mathrm{H}$ NMR: $\delta 5.92\left(\mathrm{ddt}, 1 \mathrm{H}, J_{1}=10.3 J_{2}\right.$ $\left.=17.1, J_{3}=5.7 \mathrm{~Hz},=\mathrm{CH}-\mathrm{O}\right), 5.30\left(\mathrm{ddt}, 1 \mathrm{H}, J_{1}=3.0 J_{2}=17.1\right.$ $J_{3}=1.5 \mathrm{~Hz}, \mathrm{CH}=\mathrm{C}-\mathrm{C}$, trans), $5.23\left(\mathrm{ddt}, 1 \mathrm{H}, J_{1}=3.0 J_{2}=10.3\right.$ $J_{3}=1.5 \mathrm{~Hz}, \mathrm{CH}=\mathrm{C}-\mathrm{C}$, cis $), 4.57\left(\mathrm{dt}, 2 \mathrm{H}, J_{1}=5.7 J_{2}=1.5 \mathrm{~Hz}\right.$, $\left.\mathrm{CH}_{2}-\mathrm{O}\right), 2.33$ (t, 2H, $\left.J_{1}=7.5 \mathrm{~Hz},-\mathrm{CH}_{2} \mathrm{COO}\right), 1.62\left(\mathrm{dt}, 2 \mathrm{H}, J_{1}\right.$ $\left.=J_{2}=7.2 \mathrm{~Hz},-\mathrm{CH}_{2}-\mathrm{C}-\mathrm{CO}\right), 1.26\left(\mathrm{~m}, 16 \mathrm{H},-\left(\mathrm{CH}_{2}\right)_{8}-\right), 0.90(\mathrm{t}$, $\left.3 \mathrm{H}, J=6.0 \mathrm{~Hz}, \mathrm{CH}_{3}-\mathrm{C}\right) .{ }^{13} \mathrm{C} \mathrm{NMR}: \delta 173.5,132.3,118.0,64.9$, 34.3, 31.9, 29.6, 29.4, 29.3, 29.2, 29.1, 29.1, 24.9, 22.7, 14.1 . MS (m/z): 240(1\%).

Butyl dodecanoate: ${ }^{1} \mathrm{H}$ NMR: $\delta 4.07(\mathrm{t}, 2 \mathrm{H}, J=6.6 \mathrm{~Hz}$, $\left.-\mathrm{CH}_{2}-\mathrm{O}\right), 2.29$ (t, 2H, $\left.J=7.5 \mathrm{~Hz},-\mathrm{CH}_{2} \mathrm{COO}\right), 1.61\left(\mathrm{dd}, 4 \mathrm{H}, J_{1}\right.$ $\left.=6.8, J_{2}=7.7 \mathrm{~Hz},-\mathrm{CH}_{2}-\mathrm{C}-\mathrm{COO},-\mathrm{CH}_{2}-\mathrm{C}-\mathrm{O}\right), 1.44(\mathrm{~m}, 2 \mathrm{H}$, $\left.\mathrm{CH}_{2}-\mathrm{C}-\mathrm{O}\right), 1.29$ (d, $\left.16 \mathrm{H}, J=5.3 \mathrm{~Hz},-\left(\mathrm{CH}_{2}\right)_{8^{-}}\right), 0.91\left(\mathrm{td}, 6 \mathrm{H}, J_{1}\right.$ $\left.=6.9, J_{2}=10.2 \mathrm{~Hz}, \mathrm{CH}_{3}-\mathrm{C}-\mathrm{C}-\mathrm{O}, \mathrm{CH}_{3}-\mathrm{C}\right) .{ }^{13} \mathrm{C}$ NMR: $\delta 174.0$, 64.1, 34.4, 31.9, 30.7, 29.6, 29.5, 29.3, 29.3, 29.1, 25.0, 22.7, 19.1, 14.1, 13.7. MS (m/z): 256(2\%).

Pentyl dodecanoate: ${ }^{1} \mathrm{H}$ NMR: $\delta 4.06(\mathrm{t}, 2 \mathrm{H}, J=6.7, \mathrm{~Hz}$ $\left.-\mathrm{CH}_{2}-\mathrm{O}\right), 2.31\left(\mathrm{dd}, 4 \mathrm{H}, J_{1}=6.7, J_{2}=14.0 \mathrm{~Hz},-\mathrm{CH}_{2} \mathrm{COO}\right), 1.58$ (m, $\left.4 \mathrm{H},-\mathrm{CH}_{2}-\mathrm{C}-\mathrm{COO},-\mathrm{CH}_{2}-\mathrm{C}-\mathrm{O}\right), 1.27\left(\mathrm{~m}, 20 \mathrm{H},-\left(\mathrm{CH}_{2}\right)_{8^{-}}\right.$, $-\mathrm{CH}_{2}-\mathrm{CH}_{2}$ ), 0.89 (q, $6 \mathrm{H}, \mathrm{J}=6.7 \mathrm{~Hz}, \mathrm{CH}_{3}-\mathrm{C}-\mathrm{C}-\mathrm{O}, \mathrm{CH}_{3}-\mathrm{C}$ ). ${ }^{13} \mathrm{C}$ NMR: $\delta$ 174.1, 64.4, 34.4, 31.9, 29.5, 29.3, 29.3, 29.1, $28.3,28.12,27.9,25.0,22.7,22.5,22.3,14.1,13.9 . \mathrm{MS}(\mathrm{m} / \mathrm{z})$ : $270(3 \%)$. 


\section{Characterization of supported enzymes}

\section{Scanning electron microscopy}

For scanning electron microscopy (SEM) visual analysis, Novozym 435, PS-CI and PS-DI, before and after the esterification process were mounted directly on the holders and then observed at $20 \mathrm{Kv}$ in a JEOL JSM-590-LD electron microscopy. The microanalysis was done with an EDS (Energy X-ray Dispersive Spectroscopy) system.

\section{Surface Areas, BET $\left(\mathrm{S}^{\mathrm{BET}}\right)$}

The BET specific areas were determined by standard multipoint techniques of nitrogen adsorption using a Belsorp max instrument (Bel Japan, Inc). The samples were heated at $373 \mathrm{~K}$ for 2 $\mathrm{h}$ before specific surface areas were measured.

\section{Results and discussion}

\section{Optimum temperature for enzymatic esterification}

The influence of temperature on esterification reactions was evaluated systematically with three different lipases (Novozym 435, PS-CI and PS-DI), lauric acid and butanol, They were used at different temperatures $\left(35^{\circ} \mathrm{C}, 45^{\circ} \mathrm{C}\right.$ and $\left.55^{\circ} \mathrm{C}\right)$. Butanol was selected since in these conditions it showed good kinetics, allowing more accurate measurements. The effects of reaction temperature can be attributed to its effect on substrate solubility as well as to its direct influence on the reaction and the enzyme[13]. Higher reaction temperatures also promote collisions between substrate and the enzyme resulting in accelerated reaction rates [14].

The behavior of the esterification reaction with lipase of Novozym 435 with increasing temperature is shown in Figure 1. Initially, the conversion percentage of butyl ester was increased with increasing temperature from $35^{\circ} \mathrm{C}$ to $55^{\circ} \mathrm{C}$. The conversion was almost constant at maximum range of $45-55$

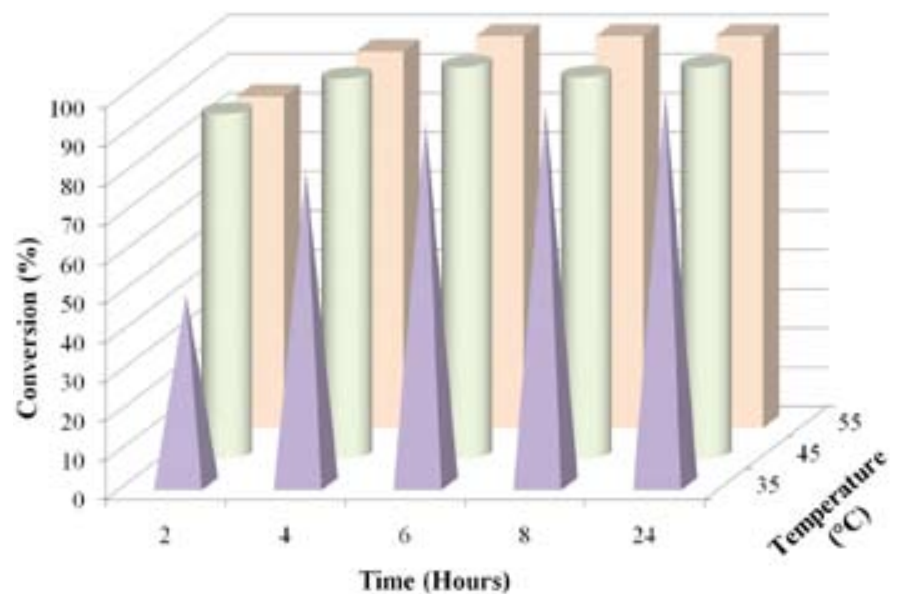

Fig. 1. Effect of temperature on Novozym 435-catalyzed esterification. $15 \mathrm{mg}$ of enzyme, $0.01 \mathrm{~mol}$ of lauric acid, $0.01 \mathrm{~mol}$ of $n$-alcohol (butanol) and $15 \mathrm{~mL}$ of hexane were introduced at different temperatures $\left(35-55^{\circ} \mathrm{C}\right)$ and two hours of reaction time.
${ }^{\circ} \mathrm{C}(72-98 \%)$ after $6 \mathrm{~h}$. Figure 1 shows the effect of temperature on initial reaction rate: as the temperature is increased the reaction rate increased. This could be due to an increase in the rate constant with temperature and partly due to an increase in interfacial area.

The conversion was nearly $99 \%$ in the presence of PS-CI; this conversion was consistent within a range of temperature 35 ${ }^{\circ} \mathrm{C}-55{ }^{\circ} \mathrm{C}$. The highest yield of butyl ester (99\%) was achieved at $55^{\circ} \mathrm{C}$ after $6 \mathrm{~h}$ of reaction and then the product remained constant for $24 \mathrm{~h}$. These results are displayed in Figure 2.

As shown in Figure 3, a conversion of more than $40 \%$ was achieved by heating at $35^{\circ} \mathrm{C}$ after $24 \mathrm{~h}$ of reaction using PS-CI.

\section{Effect of chain length of $\boldsymbol{n}$-alcohol}

The effect of chain length of $n$-alcohol for enzymatic esterification has been investigated in this study. Six different $n$-alco-

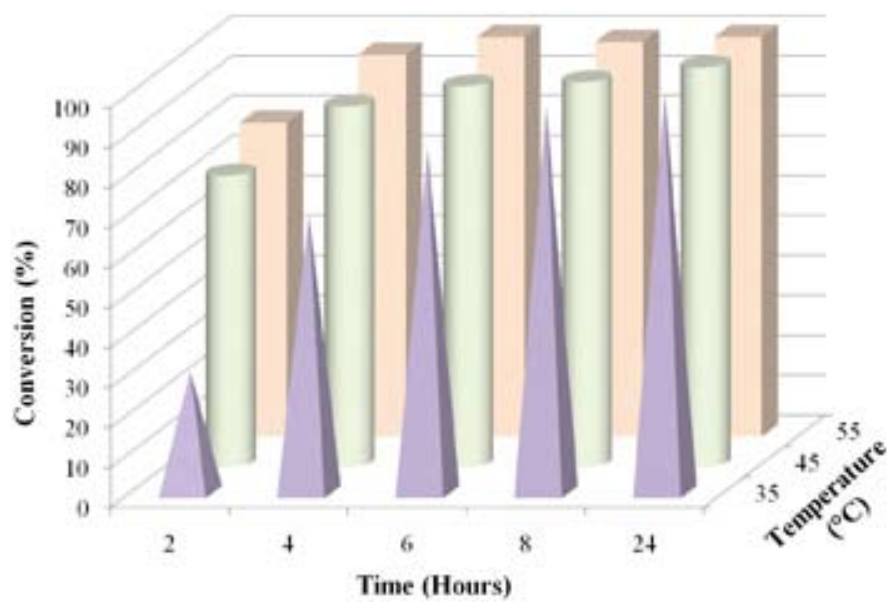

Fig. 2. Effect of temperature PS-CI catalyzed esterification. Were introduced $15 \mathrm{mg}$ of enzyme, $0.01 \mathrm{~mol}$ of lauric acid, $0.01 \mathrm{~mol}$ of $n$ alcohol and $15 \mathrm{~mL}$ of hexane at different temperatures $\left(35-55^{\circ} \mathrm{C}\right)$.

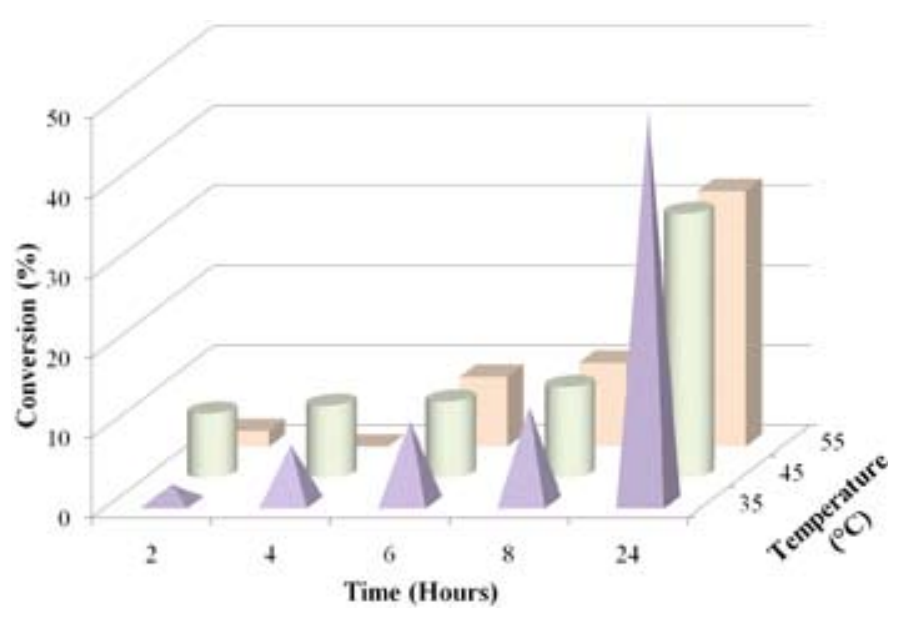

Fig. 3. Effect of temperature PS-DI-Catalyzed esterification. Were introduced $15 \mathrm{mg}$ of enzyme, $0.01 \mathrm{~mol}$ of lauric acid, $0.01 \mathrm{~mol}$ of $n$ alcohol and $15 \mathrm{~mL}$ of hexane at different temperatures $\left(35-55^{\circ} \mathrm{C}\right)$. 
hols; methanol, ethanol, $n$-propanol, $n$-butanol, $n$-pentanol and allyl alcohol were used $0.01 \mathrm{~mol}$ of each alcohol was reacted with 0.01 mol lauric acid to study the effect of chain length (Scheme 1). The conversion of lauric acid is a clear function of the type of alcohol. The conversion was nearly $99 \%$ in the presence of Novozym 435 for all alcohols, after six hours of reaction. These results show that the reaction rate is higher for most alcohols except for butane, which shows a lower rate; this allowed to study their kinetics (Figure 4).

As shown in Figure 5, the esterification of lauric acid catalyzed by PS-CI was most selective for alcohol chain lengths of C1, C2, C3 and C4 with overall conversion of $94-100 \%$ in 24 h, C5 conversion was less than 5\%, and allyl alcohol showed no reaction.

The conversions were less than $16 \%$ with methanol in the presence of PS-DI (Figure 6) for $2 \mathrm{~h} . \mathbf{C 2}, \mathbf{C 3}, \mathbf{C 5}$ began to react

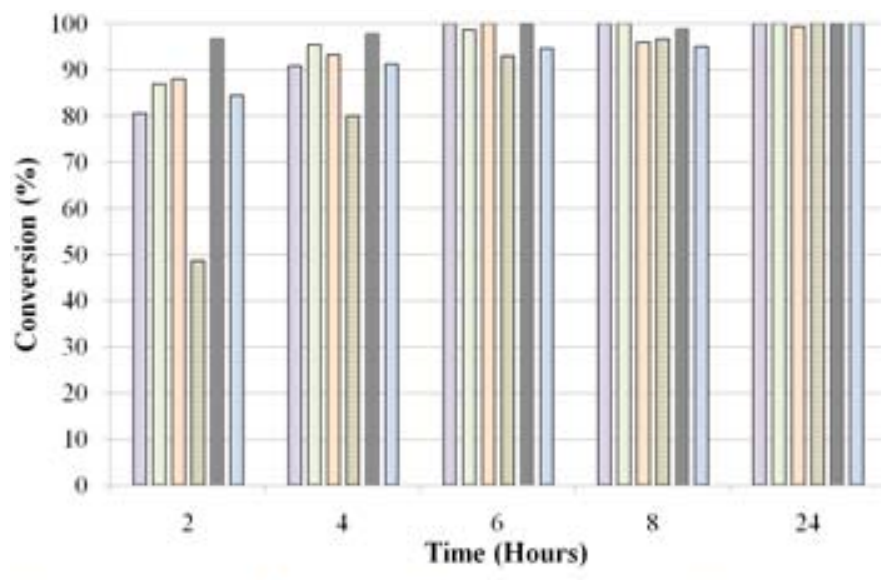

$\square$ methanol $\square$ ethanol $\square$ n-propanol $\square$ n-butanol $=$ n-pentanol $\square$ n-allyl 1 alcohol

Fig. 4. Effect of chain length of n-alcohol on Novozym 435- catalyzed esterification. $15 \mathrm{mg}$ of enzyme, $0.01 \mathrm{~mol}$ of lauric acid, $0.01 \mathrm{~mol}$ of $\mathrm{n}$-alcohol and $15 \mathrm{~mL}$ of hexane at $55^{\circ} \mathrm{C}$ were introduced.

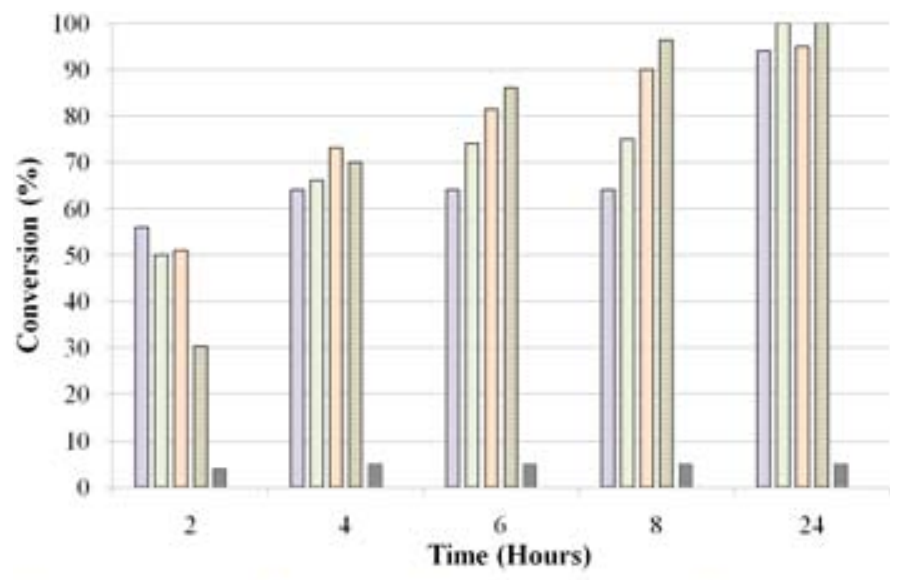

$\square$ methanol $\square$ ethanol $\square$ n-propanol $\square$ n-butanol $=$ n-pentanol $\square$ n-allyl alcohol

Fig. 5. Effect of chain length of $n$-alcohol on PS-CI- catalyzed esterification. $15 \mathrm{mg}$ of enzyme, $0.01 \mathrm{~mol}$ of lauric acid, $0.01 \mathrm{~mol}$ of $n$-alcohol and $15 \mathrm{~mL}$ of hexane at $55^{\circ} \mathrm{C}$ were introduced. after $4 \mathrm{~h}, \mathbf{C} 4$ after $6 \mathrm{~h}$ and allyl alcohol showed no evidence of reaction. This lipase was the one that showed the lowest rate of esterification reaction. The variation of the conversion with chain length of the alcohol can be attributed to the influence of factors such as molecular size of the alcohol, solubility of the alcohol in the solvent, and affinity of the lipase for the particular alcohol. This phenomenon could also be explained in terms of the binding energy that is released when a substrate binds at the active site [17].

\section{Effect of temperature on esterification under microwave irradiation}

The effect of temperature on the esterification reaction was determined using Novozym 435 as biocatalyst in the range of $40-100{ }^{\circ} \mathrm{C}$. The results are shown in Figure 7. The highest percentage of conversion was reached at $90{ }^{\circ} \mathrm{C}$ with $73.91 \%$, while the lowest conversion was obtained at $40{ }^{\circ} \mathrm{C}$. The results show that the enzyme activity increased as the temperature increased, followed by a decrease at higher temperature. The optimum reaction temperature on the activity for both PS-CI and PS-DI was $60{ }^{\circ} \mathrm{C}$; the maximum conversion was $35.74 \%$ and $15.1 \%$, respectively. It was evident that initial conversion increased with the increase of reaction temperature. However, a decrease in the conversion was observed at temperatures higher than $60^{\circ} \mathrm{C}$. This could be attributed to the deactivation of lipase at these temperatures. Microwave irradiation in the absence of the enzyme does not induce any reaction. Thus, there is a definite synergism between enzyme catalysis and microwave irradiation[18]. It is suggested that the use of microwaves as a heat source to change the interactions between the enzyme and its microenvironment prevent the thermal denaturation of the enzyme. Also, the support provides stability to the enzyme so that it does not degrade at high temperatures[19]. The effect of microwave radiation on enzyme activity is a function of enzyme hydration [20]. The microwave process, however, is fundamentally different than with conventional heating. In

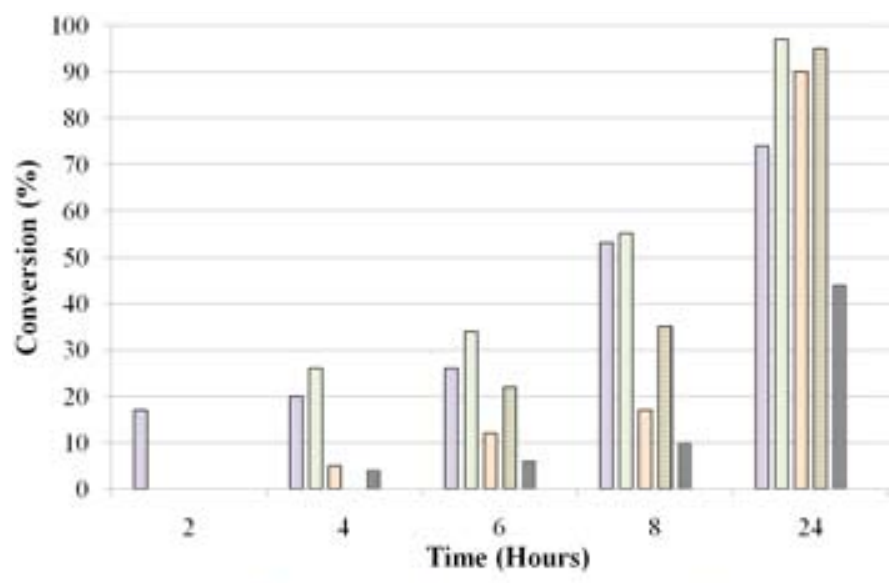

$\square$ methanol $\square$ ethanol $\square$ n-propanol $\square$ n-butanol $=$ n-pentanol $\square$ n-allyl alcohol

Fig. 6. Effect of chain length of $n$-alcohol on PS-DI-catalyzed esterification. $15 \mathrm{mg}$ of enzyme, $0.01 \mathrm{~mol}$ of lauric acid, $0.01 \mathrm{~mol}$ of $n$-alcohol and $15 \mathrm{~mL}$ of hexane at $55^{\circ} \mathrm{C}$ were introduced. 


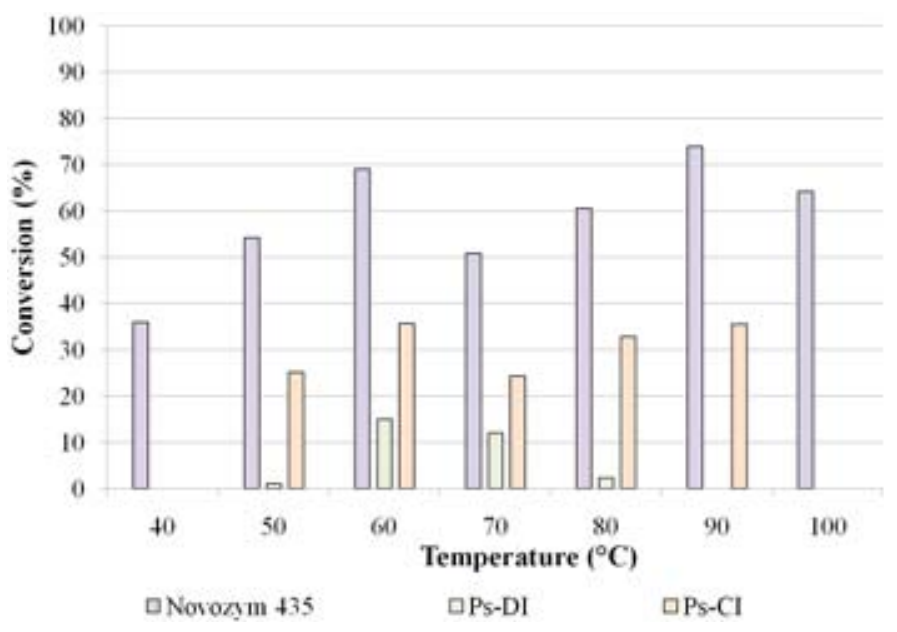

Fig. 7. Effect of temperature under microwave heating on lipase-catalyzed esterification. $15 \mathrm{mg}$ of enzyme, $0.01 \mathrm{~mol}$ of lauric acid, 0.01 $\mathrm{mol}$ of n-alcohol and $15 \mathrm{~mL}$ of different temperatures $\left(40-100{ }^{\circ} \mathrm{C}\right.$ ) were introduced. Power $20 \mathrm{~W}$, time, $4 \mathrm{~min}$.

a conventionally heated system, heat must be transferred from source into the reaction vessel via conduction and convection. In a microwave heated vessel, the microwave energy is converted to heat within the vessel through coupling with polar compounds (solvent or substrate), by the traditional mechanism of heat transfer [21].

\section{Optimization of the reaction time for esterification of lauric acid}

The effect of reaction time was also examined using Novozym 435 and butanol. From the results it can be seen that as reaction time was extended from 2 to $8 \mathrm{~min}$, the conversion of the desired product improved from $55.45 \%$ to $69.03 \%$. However, when the reaction time exceeded $4 \mathrm{~min}$, there was a decrease in the conversion (Table 1).

\section{Influence of chain length of $\boldsymbol{n}$-alcohol using microwave heating.}

Applying microwave irradiation, a series alcohols has been examined for the esterification reaction using the temperature previously established as optimal. It was found that using Novozym 435 as biocatalyst high conversions were obtained; ethanol $(81.9 \%)>$, propanol $(80 \%)>$, methanol $(77 \%)>$, butanol $(73 \%)>$, allyl alcohol $(68 \%)>$, pentanol $(13 \%)$. The PS-CI showed the highest percentage of conversion with propanol

Table 1. The effect of the reaction time on Novozym 435 catalyzed esterification under microwave heating using butyl alcohol.

\begin{tabular}{cc}
\hline Time $(\mathrm{min})$ & Conversion $(\%)$ \\
\hline 2 & 66.75 \\
4 & 69.03 \\
6 & 55.45 \\
8 & 63.01 \\
\hline
\end{tabular}

(65\%) and Ps-DI the lowest conversion. All these results are shown in the Figure 8.

\section{Characterization of supported enzymes}

\section{Scanning electron microscopy}

Figure 9 (A, B, C, D) shows the morphology of PS-CI as small balls with a cavity in the center. (A) Corresponds to fresh material, (B) shows the morphology of PS-CI at $55^{\circ} \mathrm{C},(\mathrm{C})$ at $60^{\circ} \mathrm{C}$ and (D) at $90^{\circ} \mathrm{C}$. Little changes in the morphology occur after the microwave heating process and the important feature was the increase in the elemental and atomic percentage of carbon and oxygen after the process (Table 2).

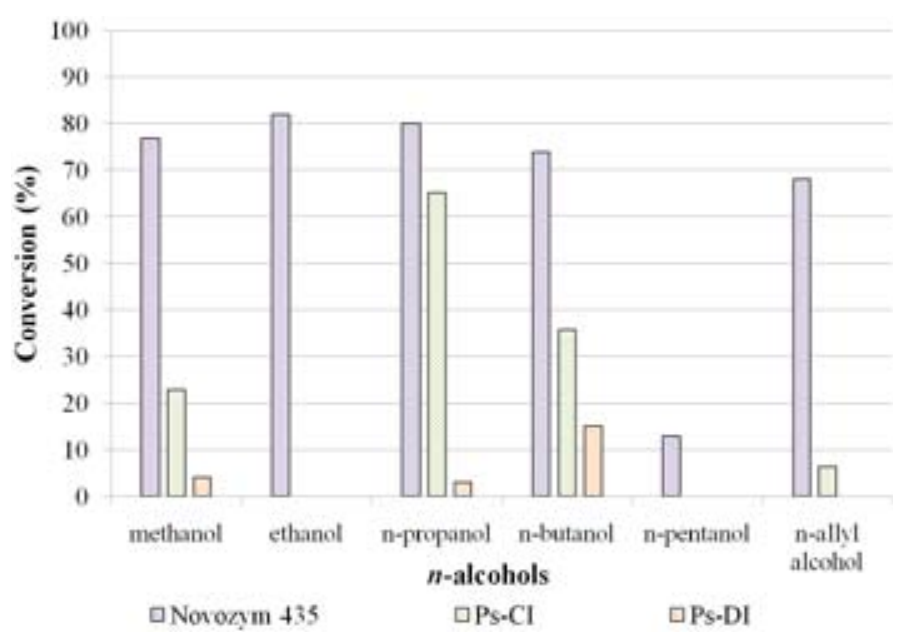

Fig. 8. Effect of chain length of n-alcohol under microwave heating on lipase-Catalyzed esterification. $15 \mathrm{mg}$ of enzyme, $0.01 \mathrm{~mol}$ of lauric acid, $0.01 \mathrm{~mol}$ of $\mathrm{n}$-alcohol and $15 \mathrm{~mL}$ of hexane were introduced. Power $20 \mathrm{~W}$, time $4 \mathrm{~min}$.

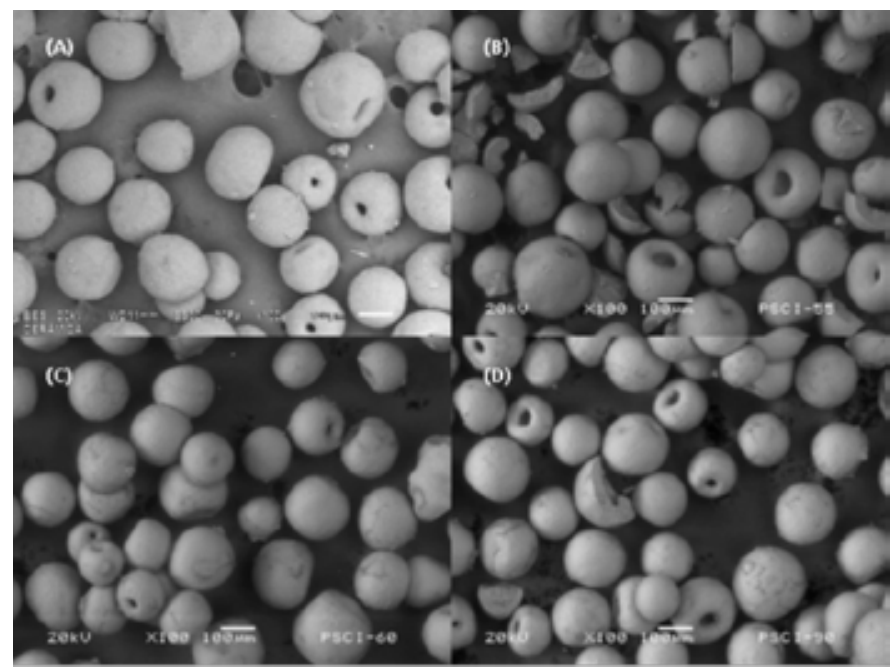

Fig. 9. Scanning electron micrograph of the lipase of PS-CI. A) fresh enzyme B) $55^{\circ} \mathrm{C}$, C) $60^{\circ} \mathrm{C}$ and D) $90^{\circ} \mathrm{C}$. 
Table 2. Elemental analysis of PS-CI.

\begin{tabular}{|c|c|c|c|c|c|c|}
\hline Element & $\begin{array}{c}\text { PSCI-55 } \\
\text { Element } \%\end{array}$ & $\begin{array}{l}\text { PSCI-55 } \\
\text { Atomic\% }\end{array}$ & $\begin{array}{c}\text { PSCI-60 } \\
\text { Element } \%\end{array}$ & $\begin{array}{c}\text { PSCI-60 } \\
\text { Atomic } \%\end{array}$ & $\begin{array}{c}\text { PSCI-90 } \\
\text { Element } \%\end{array}$ & $\begin{array}{l}\text { PSCI-90 } \\
\text { Atomic } \%\end{array}$ \\
\hline $\mathrm{C}$ & 29.12651 & 40.6572 & 42.80531 & 55.30415 & 35.62479 & 47.80749 \\
\hline $\mathrm{Al}$ & 7.082833 & 4.401097 & 5.242926 & 3.015357 & 6.005168 & 3.58735 \\
\hline $\mathrm{Si}$ & 24.40524 & 14.56871 & 18.00128 & 9.946094 & 20.92361 & 12.00796 \\
\hline $\mathrm{Fe}$ & 0.360617 & 0.108262 & 0.26983 & $7.50 \mathrm{E}-02$ & 0.140899 & 4.07E-02 \\
\hline $\mathrm{Ca}$ & & & 0.437964 & 0.16957 & 0.508489 & 0.204492 \\
\hline $\mathrm{P}$ & & & 0.347559 & 0.174128 & 0.396241 & 0.206198 \\
\hline $\mathrm{Cl}$ & & & 0.133863 & $5.86 \mathrm{E}-02$ & & \\
\hline
\end{tabular}

This lipase is stabilized in a ceramic support, which also behaves as adsorbent as shown by elemental analysis. The increasing content of carbon and oxygen are indicative of retention of lauric acid and its ester in the support; other elements such as calcium, phosphorus and chlorine elements have been retained by the ceramic which were dissolved in the reaction solvent.

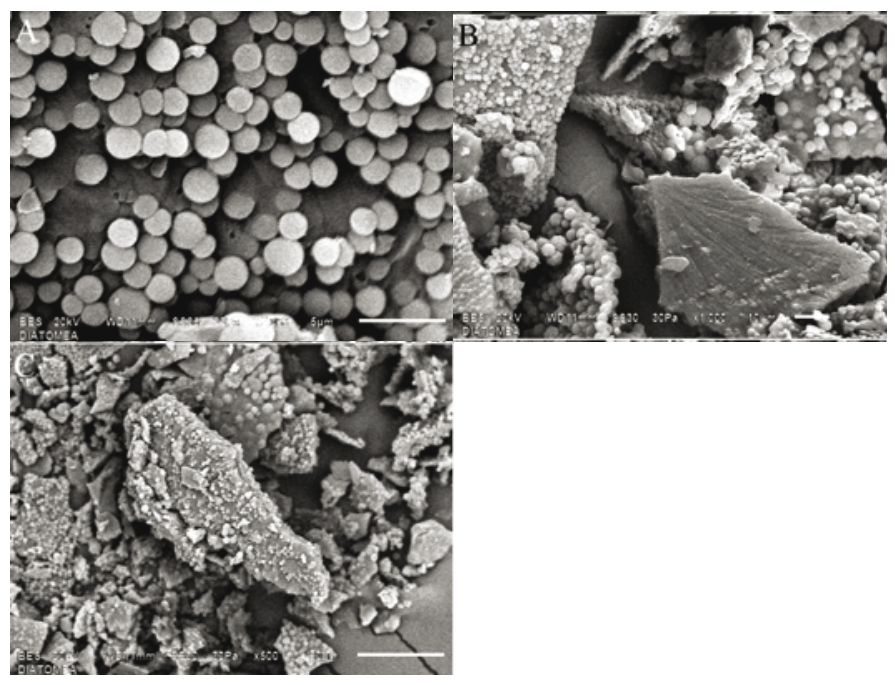

Fig. 10. Scanning electron micrograph of the lipase of PS-DI. A) fresh enzyme, esterification reaction; B) at $55^{\circ} \mathrm{C}$ and C) at $90{ }^{\circ} \mathrm{C}$.
Figure 10A shows the SEM of fresh PS-DI which showed unchanged biocatalyst particles with uniform and firm distribution. Figures $10 \mathrm{~B}$ and $10 \mathrm{C}$ show the SEM of PS-DI used at $55^{\circ} \mathrm{C}$ and $90{ }^{\circ} \mathrm{C}$, respectively. Figure $10 \mathrm{~B}$ shows the SEM of PS-DI at $55^{\circ} \mathrm{C}$; the enzyme layer over the matrix support has peeled off from the surface in the esterification, reducing the amount of enzyme present of the matrix. The effect of PS-DI at $90{ }^{\circ} \mathrm{C}$ under microwave irradiation induce disintegration of the matrix and consequently degradation of the enzyme.

SEM micrographs of Novozym 435 before and after reaction at $55^{\circ} \mathrm{C}$ and $90^{\circ} \mathrm{C}$, respectively are shown in Figure 11 . The external texture of the beads exposed to microwave heating shows a scratched surface compared with non-treated Novozym 435 as observed in Figures 11B and $11 \mathrm{C}$, respectively.

The effect of microwaves on the surface of the immobilized enzymes was observed by microscopy techniques; minor structural changes were observed on the surface of the support-lipase of PS-CI. The external texture of Novozym 435 of the beads exposed under microwave heating shows an evident scratched surface. However, lower yields may occur due to inhibition of enzyme. While activity measurement is with respect to lauric acid, the yields referred to here are for the formation of laurate ester.

\section{Surface Areas, BET $\left(\mathrm{S}^{\mathrm{BET}}\right)$}

The studies of fisisorption were made on supported enzymes, Figure 12 shows the isotherms of the adsorption/desorption

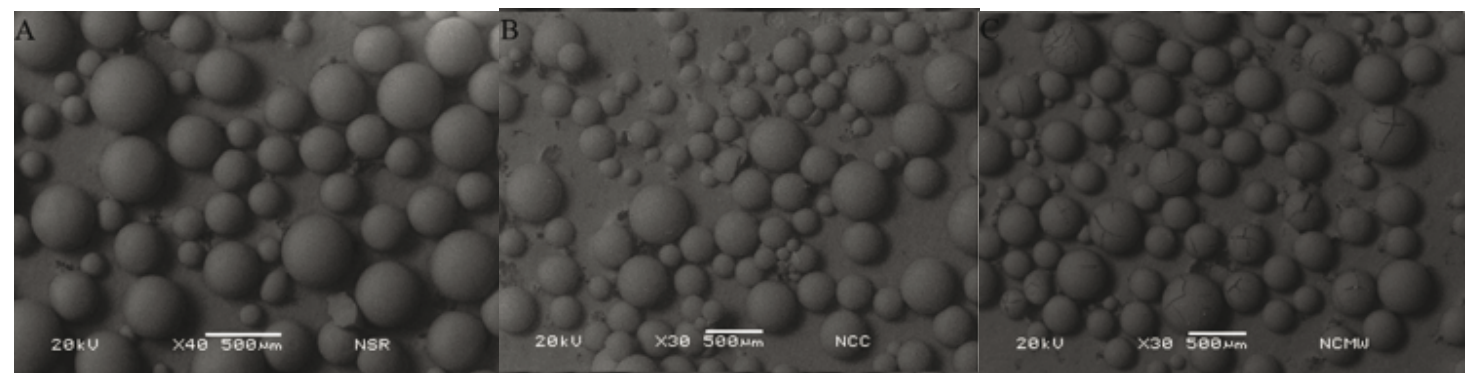

Fig. 11. Scanning electron micrograph of Novozym 435. A) fresh enzyme, esterification reaction; at B) $55^{\circ} \mathrm{C}$ and $\left.\mathrm{C}\right) 90{ }^{\circ} \mathrm{C}$. 


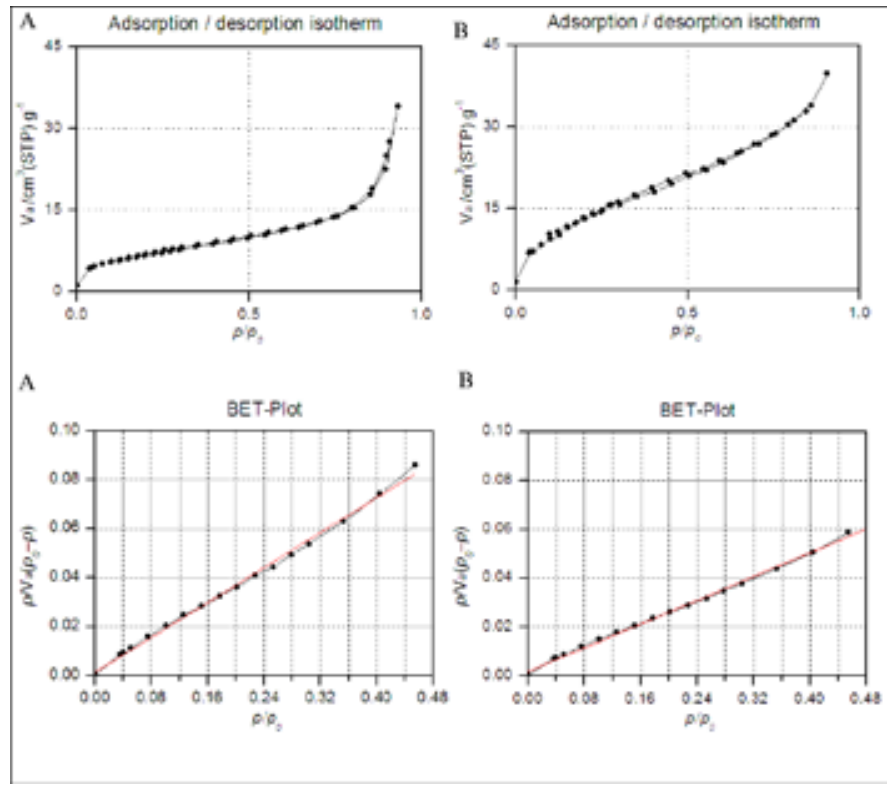

Fig. 12. Absorption/desorption isotherm and BET of the lipase Pseudomona cepacia supported on ceramic.

process and BET. In this way it was possible to determine the surface area and its behavior on fresh material and after the esterification reaction under microwave heating $\left(90^{\circ} \mathrm{C}\right)$. There were no significant changes in the areas before $\left(24.96 \mathrm{~m}^{2} \mathrm{~g}^{-1}\right)$ and after $\left(26.96 \mathrm{~m}^{2} \mathrm{~g}^{-1}\right)$ the synthetic process.

\section{Conclusion}

The behavior of three commercial lipases was established in the esterification of lauric acid with six linear $n$-alcohols (methanol to pentanol and allyl alcohol) in hexane. These lipases maintained their activity for several cycles (three times) at temperatures up to $90{ }^{\circ} \mathrm{C}$; this is indicative of the stability that support provides. The optimum temperatures were established: for the lipases Novozym 435 and PS-CI was $55^{\circ} \mathrm{C}$, and for PS-DI was $45^{\circ} \mathrm{C}$. A comparative study using microwave heating was performed, and the optimum temperatures were established: for the lipases PSCI and PS-DI was $60^{\circ} \mathrm{C}$, and Novozym 435 was $90^{\circ} \mathrm{C}$. Novozym 435 was found to be the most effective among the three enzymes studied; the rates of enzymatic esterification of lauric acid showed the trend, methanol $>$ ethano $1>$ propanol $>$ butanol. The same behavior was observed under microwave and conventional heating. The selectivity order was established for each lipase with the respective alcohols. The lipases have shown to possess a high discriminating ability toward the different alcohols depending upon chain length. The microwave effect was to reduce the reaction time from $24 \mathrm{~h}$ to 6 min, maintaining its activity (three cycles). The technique of SEM allows the determination of the physical state of the Enzyme support and EDS provides the elemental analysis in the process.

\section{Acknowledgments}

We gratefully acknowledge support for this project by Consejo Nacional de Ciencia y Tecnología, México (CONACyT, GRANT No. SEP-201-47835). Thanks to Novozymes de México for kind gift of Novozym 435. Velia Osuna thanks CONACyT for graduate scholarship.

\section{Supplementary Materials}

${ }^{1} \mathrm{H}$ NMR and ${ }^{13} \mathrm{C}$ NMR spectra for all reactions products are available.

\section{References}

1. Ali, S.; Tarakmah, A. ;Merchant, S.; Alsahhaf, T. Chem. Eng. Technol. 2007, 62, 3197-3217.

2. Aysha, T.; Lunak, S.; Lycka, A.; Hrdina, R. Dyes and Pigm. 2011, 91, 170-176.

3. Schmid, A.; Dordick, J.; Haver, B.; Kiener, A.; Wubbolts, M.; Witholt, B. Nature 2001, 409, 258-268.

4. Lee, M.; Dordick, J. J. Curr. Opin. Biotechnol. 2002, 13, 376384.

5. Sheldon, R. Green Chem. 2007, 9, 1273-1283.

6. Turner, N. Nat. Chem. Biol. 2009, 5, 567-573.

7. a) Gotor-Fernandez, V.; Brieva, R.; Gotor, V. J. Mol. Catal. B: Enzymatic 2006, 40, 111-120. b) Rajan, A.; Abraham. T.E. Bioprocess and Biosystems Engineering 2006, 29(1), 65-71. c) Rajan, A.; Sudha, J.D.; Abraham, T.E. Industrial Crops and Products 2008, 27, 50-59.

8. Rocha, J.; Gil, M.; García, F. J. Chem. Technol. Biotechnol. 1999, 74, 607-612.

9. Yadav, G.; Sivakumar, P. Biochem. Eng. J. 2004, 19, 100-107.

10. Gotor, V.; Brieva, R.; Gonzalez, C.; Rebolledo, F. Tetrahedron 1991, 47, 9207-9214.

11. a) Yadav, G.D.; Borkar, I.V. Industrial \& Engineering Chemistry Research 2008, 47(10), 3358-3363. b) Bezbradica. D.; Mijin, D.; Mihailovic, M.; Knezevic-Jugovic, Z. Journal of Chemical Technology and Biotechnology 2009, 84(11), 1642-1648. c) Yadav, G.D.; Lathi, P.S. Synth. Commun. 2005, 35(12), 1699-1705

12. a) Horchani, H.; Chaabouni, M.; Gargouri, Y.; Sayari, A. Carbohydrate Polymers 2010, 79(2), 466-474. b) Rejasse, B.; Lamare, S.; Legoy, M.D.; Besson, T. Journal of Enzyme Inhibition and Medicinal Chemistry 2007, 22(5), 518-526. c) Rufino, A.R.; Biaggio, F.C.; Santos, J.C.; de Castro, H.F. Inter. J. Bio. Macromol 2010, 47(1), 5-9. d) Rufino, A.R.; Biaggio, F.C.; Santos, J.C.; de Castro, H.F. Inter. J. Bio. Macromol. 2010, 47(1), 5-9.

13. Hayes, B. Microwave synthesis: Chemistry at the speed of light, CEM Publishing, Mattews NC, 2002, 29-74.

14. Kidwail, M.; Poddar, R.; Mothsra, P. Beil J. Org. Chem. 2009, 5, 10-12.

15. Facioli, N.; Barrera, A. J. Sci. Food 2001, 12, 1193-1198.

16. Ghaffari, M.; Ahmad, F.; Basri, M.; Abdul, M. J. Applied. Sci. 2010, 10, 337-342.

17. Shintre, M.; Ghadge, R.; Sawant, S. J. Chem. Technol. Biotechnol. 2002, 77, 1114-1121.

18. Yadav, G.; Borkar, I. Ind. Eng.Chem. Res. 2009, 48, 7915-7922.

19. Varma, M.; Madras, G. Appl. Biochem. Biotechnol. 2010 160, 2342-2354.

20. Banik, S.; Bandyipadhyay,S. Bioresour Technol. 2003, 87 155159.

21. Yadav, G.; Sajgure. A. J. Chem. Technol. Biotechnol. 2007, 82, 964-970. 